\title{
Tri Sukses Melalui Bimbingan dan Konseling Pendidikan Sesuai Faktor Sosial Budaya
}

\author{
Farida \\ STAIN Kudus, Jawa Tengah, Indonesia \\ tofapustaka@gmail.com
}

\begin{abstract}
Abstrak
Setiap manusia membutuhkan pendidikan sebagai usaha sadar untuk memandirikan manusia. Maka guru yang sukses memberikan pendidikan adalah yang mampu mengoptimalkan kemampuan kognitif (sukses prestasi akademik), yang memiliki motivasi untuk masa depan cerah (sukses karir), serta berpartisipasi aktif dalam aktivitas di lingkungan sosial keagamaan (sukses sosial). Rumusan masalah yang diangkat dalam penelitian ini adalah: 1) Apa itu Tri Sukses? 2). Bagaimana Tri Sukses melalui bimbingan dan konseling pendidikan? Tujuan dalam penelitian ini adalah untuk mengetahui tri sukses melalui bimbingan dan konseling. Metode yang digunakan dalam penelitian ini adalah metode studi pustaka, yakni pengumpulan data dan informasi dengan menelaah sumber-sumber tertulis seperti jurnal ilmiah, buku referensi, literature, ensiklopedia, karangan ilmiah, serta sumber-sumber lain yang terpercaya baik dlm bentuk tulisan atau dalam format digital yang relevan dan berhubunga dengan objek yang diteliti. Berdasarkan uraian dalam pembahasan, hasil yang dapat disimpulkan bahwa menjadi peserta didik adalah kesempatan untuk menyempurnakan tugas-tugas perkembangan, mengoptimalkan semua potensi yang dimiliki sehingga meraih tri sukses: sukses akademik, sukses karir, dan sukses sosial. Dalam mewujudkan tri sukses membutuhkan bimbingan dan konseling pendidikan Islam dengan iklim belajar yang kondusif.

Kata Kunci: Tri sukses; bimbingan konseling; pendidikan.
\end{abstract}




\title{
Tri Sukses Melalui Bimbingan dan Konseling Pendidikan ...
}

\begin{abstract}
Every human being needs education as a conscious effort to create humanity. So teachers who successfully provide education are able to optimize cognitive abilities (successful academic achievement), who have motivation for a bright future (successful career), as well as actively participate in activities in the social-religious environment (social success). The formulation of the problems raised in this study are: 1) What is Tri Success? 2) How is Tri Sukses through education guidance and counseling? The purpose of this research is to know the tri success through guidance and counseling. The method used in this study is the literature study method, namely data collection and information by reviewing written sources such as scientific journals, reference books, literature, encyclopedias, scientific articles, and other reliable sources either in writing or in format digital relevant and related to the object studied. Based on the description in the discussion, the results can be concluded that being a student is an opportunity to perfect the development tasks, optimize all the potential that has to achieve tri success: academic success, career success, and social success. In realizing tri success requires guidance and counseling of Islamic education with a conducive learning climate.
\end{abstract}

Keywords: Tri success; counseling guidance; education.

\section{A. Pendahuluan}

Manusia lahir dalam kondisi bersih. Data-data dalam otaknya jernih, belum mengerti makna dan bahasa apapun bahkan belum mengerti apa yang terjadi di sekitarnya. Seiring waktu berjalan, tumbuh besar. Berbagai pengetahuan memberinya pengertian tentang apa yang ditangkap dan menggambarkan pengertian. Dengan pengalaman, akal manusia akan merekamnya dalam memori khusus di otak (Elfky, 2013: 14). Melalui pendidikan, manusia mendapatkan pengetahuan, pengertian, pengalaman, pemahaman, pemaknaan yang membuatnya semakin mandiri. Sehingga dengan pendidikan menjadikan manusia bertanggung jawab atas dirinya sendiri dan menyadari kemampuan untuk berfungsi dengan keterlibatan di lingkungan masyarakat. 
Istilah pendidikan (Faqih, 2001: 92), yaitu usaha sadar untuk membantu manusia mengenali dan menyesuaikan dengan lingkungan, mengetahui berbagai pengetahuan, serta mengembangkan potensi yang dimiliki untuk memberi kemanfaatan pada diri sendiri dan orang lain, teraktualisasikan kemampuan berpikir-berperasaan-bertindak. Pendidikan dilakukan oleh orang dewasa, misalnya: orang tua mendidik anaknya, guru mendidik peserta didik, serta tokoh masyarakat mendidik dengan memberikan keteladanan untuk anggota masyarakatnya. Pada kesempatan ini, pembahasan menekankan pada pendidikan di lembaga pendidikan: sekolah dan Madrasah.

Menurut Clark bahwa sekolah dan Madrasah di Indonesia cenderung mengutamakan pendidikan ke arah penguasaan iptek, namun lemah dalam pengembangan kepribadian beriman, bertakwa, kreatif dan punya perasaan kemanusiaan, intuisi dan daya tanggap. Tekanan sistem sekolah yang berorientasi pengembangan otak kiri (untuk menguasai iptek) sering membuat peserta didik jenuh, frustasi, dan konflik karena tidak mempunyai pilihan lain kecuali belajar dan menghafal. Akibatnya hasil belajar kurang memuaskan dan muncul gejala-gejala membolos, malas, pertengkaran, menentang guru, dan perkelahian ataupun tawuran (Willis, 2013: 26). Karena pengalaman iptek hanya mengembangkan aspek logika, sedangkan aspek rasa senang-tertarik-berminat tidak menjadi perhatian pendidikan. Yang mencetak peserta didik untuk cerdas tapi tidak memiliki kepedulian sosial dan kurang sopan kepada orang lain. Maka akan terjadi kondisi yang tidak seimbang antara pesatnya kemajuan otak dengan kondisi perasaan, yang akan memunculkan rasa cemas pada peserta didik di lingkungan pendidikan dengan semua aturan kependidikan: tata tertib Madrasah, kedisiplinan dalam proses belajar, etika interaksi dengan guru maupun teman sebaya.

Di sekolah dan Madrasah, banyak faktor pemicu timbulnya kecemasan peserta didik, yaitu: target kurikulum yang tinggi, iklim pembelajaran yang tidak kondusif, pemberian tugas yang sangat padat, serta sistem penilaian ketat dan kurang adil. Begitu juga, sikap dan perlakuan guru yang kurang bersahabat, galak, judes dan kurang kompeten. Selain itu, penerapan disiplin sekolah yang ketat, iklim 


\section{Tri Sukses Melalui Bimbingan dan Konseling Pendidikan ...}

sekolah yang kurang nyaman, serta sarana prasarana belajar yang sangat terbatas, serta kurangnya manajemen sekolah. Mengingat dampak negatifnya terhadap pencapaian prestasi belajar dan kesehatan fisik-mental peserta didik maka perlu ada upaya-upaya tertentu untuk mencegah dan mengurangi kecemasan peserta didik (Hasyim, dkk, 2010: 223) dengan pendekatan individu, yakni memahami perbedaan kebutuhan-minat-kemampuannya. Karena di dalam pendidikan terdapat proses usaha sadar untuk mencapai tri sukses, yaitu: akademik, karir, peran sosial. Hal tersebut dapat dilakukan oleh setiap individu dengan menyadari kelemahan dan kelebihan yang dimiliki.

Tugas pokok individu pembelajar adalah menata atau mengolah keadaan diri sendiri dari luar diri untuk bisa mendukung upaya belajar atau pendidikannya. Individu bisa menyiapkan kondisi diri sendiri atau kondisi serta situasi lingkungan sebaik-baiknya agar mendukung keberhasilan belajar/mengajar, menjadi persoalan yang utama. Termasuk tugas pendidik untuk menciptakan kondisi dan situasi yang memungkinkan seseorang yang dididiknya bisa belajar dan baik (Faqih, 2001: 104). Sehingga pendidik maupun iklim belajar yang nyaman dengan memahami kondisi peserta didik, yang menjadikan proses belajar tidak hanya transfer pengetahuan, tetapi juga ada keteladanan dan penerapan nilai-nilai kebaikan serta upayaupaya dalam menyelesaikan permasalahan. Oleh karenanya, guru diharapkan memiliki kemampuan untuk memberikan bimbingan dan konseling kepada peserta didik, baik di dalam kelas maupun di luar jam belajar.

Menurut Tolbert yang dikutip Winkel (1991) bahwa konseling adalah bantuan pribadi secara tatap muka antara dua orang, yaitu seorang disebut konselor yang berkompeten dalam bidang konseling membantu seorang yang disebut konseli yang berlangsung dalam situasi belajar, agar konseli dapat memperoleh pemahaman baik tentang dirinya dan pemahaman tentang situasi sekarang dan akan datang. Sebagai hubungan bantuan yang bersifat pribadi, konselor menggunakan teknik-teknik hubungan yang efektif dan sebagai bentuk intervensi maka bantuan profesional konselor untuk memengaruhi konseli mengubah perilakunya ke arah yang lebih maju (progressive). Dan sebagai proses psikologis, konseling 
dibangun konselor dengan menggunakan teori-teori psikologi yang sesuai karakteristik konseli. Maka konseling bukan sebagai proses yang tetap, melainkan bergerak ke arah maju sejalan dengan kemajuan proses berpikirnya konselor dan konseli (Hartono, dkk, 2013: 29). Sehingga proses konseling dapat dijadikan kesempatan belajar untuk merubah sikap ke arah yang lebih baik sesuai dengan kondisi konseli setelah mengenali kelemahan, kelebihan, kebutuhan, keinginan, serta dituntun oleh cita-citanya untuk sukses di masa depan. Karena kesuksesan dalam akademik akan memudahkan kesempatan karir dan keterlibatan dalam lingkungan sosial. Maka peserta didik yang mendapatkan ilmu pengetahuan, keteladanan perilaku yang baik, serta keinginan untuk sukses dengan berlatih untuk menyelesaikan masalah dengan bimbingan dari guru akan menjadi bekal di kehidupan mendatang. Hal inilah yang menjadi alasan pentingnya bimbingan dan konseling di lembaga pendidikan, dibutuhkannya bimbingan dan konseling untuk membantu peserta didik meraih tri sukses.

Efektivitas konseling terhadap manusia tergantung pada sejauh mana pengertian dan pemahaman apa sebenarnya manusia. (May, 2003: 3). Begitu juga pemahaman tentang peserta didik, yaitu: tentang kekuatan fisiknya, kemampuan kognitifnya, kondisi perasaan, adaptasi dengan lingkungannya, minat-bakat-tujuannya belajar, prestasi serta cita-citanya. Dengan mengenali karakteristik peserta didik, maka guru dapat memberikan layanan bimbingan dan konseling sesuai dengan kebutuhan peserta didik, baik sebagai tindakan prefentif-kuratif-rehabilitatif-developmental.

Konseling merupakan pelayanan profesional yang dikemas dengan menggunakan ilmu psikologi dan pendidikan. Dalam kapasitas sebagai pendidik, konselor berperan dan berfungsi sebagai seorang pendidik psikologis atau psychoeducator (Hartono, dkk, 2013: 36). Sehingga diketahui bahwa bimbingan dan konseling tidak hanya untuk peserta didik yang bermasalah, sehingga guru BK dikesankan sebagai polisi sekolah dan tidak humanis. Karena pada kenyataannya peserta didik yang pintar, bersemangat, dan adaptif pun membutuhkan bimbingan dan arahan sehingga tetap berprestasi dan siap untuk menghadapi segala kemungkinan masalah dan mengenali sebab-sebab munculnya masalah. Sehingga dengan peran 


\section{Tri Sukses Melalui Bimbingan dan Konseling Pendidikan ...}

bimbingan dan konseling di lembaga pendidikan akan membantu peserta didik memiliki sikap positif terhadap lingkungan serta siap menghadapi hal-hal yang tidak terduga

Resiliensi merupakan satu aspek potensi yang perlu dikembangkan dalam diri peserta didik, sebab merupakan kemampuan atau kapasitas insani yang memungkinkan untuk menghadapi-mencegah-meminimalkan bahkan menghilangkan dampak yang merugikan dari kondisi yang tidak menyenangkan atau mengubah kondisi kehidupan yang menyengsarakan menjadi suatu hal yang wajar untuk diatasi. Bagi peserta didik yang resilien, resiliensi membuat hidup menjadi lebih kuat. Resiliensi membuat hidup peserta didik berhasil menyesuaikan diri dalam berhadapan dengan kondisi yang tidak menyenangkan, perkembangan sosial, akademis, kompetensi vokasonal, bahkan dengan tekanan hebat yang inheren dalam dunia sekarang (Desmita, 2014: 304). Oleh karenanya, dengan peran bimbingan dan konseling di lembaga pendidikan akan membantu peserta didik untuk menjadi pribadi yang mandiri, bertanggung jawab, lebih kuat dan siap untuk menghadapi tantangan dan peluang. Maka tri sukses akan dapat ditemukan sendiri oleh peserta didik sebagai kebutuhan dengan bantuan bimbingan dari guru. Karena Madrasah menjadi tempat kedua untuk individu tumbuh dan kembang menuntaskan tugas belajar ilmu pengetahuan, meraih cita-cita masa depan dengan semangat, serta belajar untuk berpengalaman dengan interaksi seluruh aspek pendidikan, yaitu: menghormati kepala Madrasah, patuh pada pendidik, sopan dengan semua pegawai, menyayangi teman sebaya, serta merawat semua sarana prasarana pembelajaran agar tercipta iklim pendidikan yang kondusif dan nyaman.

\section{B. Pembahasan}

Pendidikan merupakan institusi pembinaan peserta didik yang memiliki latar belakang sosial budaya dan psikologis yang beraneka ragam. Dalam mencapai maksud dan tujuan pendidikan, banyak peserta didik yang menghadapi masalah dan sekaligus mengganggu tercapainya tujuan-tujuan pendidikan. Masalah yang dihadapi beraneka ragam, diantaranya masalah: pribadi, sosial, ekonomi, agama dan moral, belajar dan vokasional. Masalah-masalah tersebut seringkali menghambat kelancara proses belajar, meskipun 
masalah yang dihadapi tidak ada sangkut pautnya dengan kegiatan akademik. Penyelenggara pendidikan, khususnya tenaga pendidikan bertanggung jawab membina anak didiknya agar berhasil sebagaimana yang diharapkan, termasuk anak didik yang mengalami masalah (Latipun, 2001: 29). Dengan mengarahkan sesuai dengan pemahaman peserta didik, di mana guru harus memiliki keyakinan bahwa setiap anak memiliki kemampuan berpikir dan mempunyai keinginan menjadi baik. Dengan akal manusia dapat mengenali lingkungan, memberikan kemanfaatan, menyelesaikan masalah, mewujudkan keinginan atau cita-cita, serta mengenal dan menghayati Tuhan dengan bertakwa.

Dan perlu untuk terus dilatih agar akal mengenali banyak ilmu pengetahuan, mencipta teknologi, serta merumuskan budaya dan perubahan-perubahan yang lebih baik dan bermanfaat untuk diri sendiri maupun lingkungan. Oleh karenanya, agar akal anak-anak berkembang secara optimal membutuhkan bimbingan dan arahan dari guru. Sehingga WaJar (Wajib Belajar) selama 12 tahun merupakan kebutuhan peserta didik untuk mendapatkan pengetahuan dan pengalaman yang tuntas, agar nantinya peserta didik saat dewasa mampu berperan sebagai pendidik untuk generasi baru sebagai wujud dari hakekat pendidikan.

Pendidikan adalah upaya mengarahkan perkembangan kepribadian (aspek psikologik dan psikofisik) manusia sesuai hakekatnya agar menjadi insan kamil, dalam rangka mencapai tujuan akhir kehidupannya, yaitu kebahagiaan hidup di dunia dan di akh9irat (Faqih, 2001: 94). Dengan menumbuhkan kesadaran pada peserta didik bahwa belajar merupakan kebutuhan, dan bersekolah merupakan hak setiap individu untuk mendapatkan pendidikan. Hal tersebut dapat dilakukan guru ketika menyampaikan materi pelajaran maupun pada waktu khusus yaitu memberikan layanan bimbingan dan konseling pendidikan.

Guru-guru bidang studi termasuk wali kelas adalah berperan sebagai pembimbing agar peserta didik termotivasi untuk berubah menuju pada kebaikan dan kesempurnaan, guru juga membantu menyelesaikan permasalahan-permasalahan peserta didik dengan efektif dan efisien. Dalam pendekatan kepada peserta didik harus manusiawi-religius, bersahabat, ramah, mendorong, konkrit, jujur 


\section{Tri Sukses Melalui Bimbingan dan Konseling Pendidikan ...}

dan asli, memahami, tidak menilai dan menghargai tanpa syarat. Karena itu strategi pengajaran haruslah berorientasi pengembangan peserta didik, dan bukan membuat peserta didik pasif (Willis, 2013: 29). Maka dibutuhkan kemampun komunikasi persuasif agar terjalin interaksi yang harmonis antara guru BK dengan peserta didik. Yang melibatkan kemampuan logis, kondisi perasaa, serta ketrampilan sikap dalam menyelesaikan masalah maupun memberikan bimbingan akademik, karir dan sosial.

Perasaan tak ubahnya bahan bakar bagi manusia. Perasaan adalah reaksi alamiah dari pikiran dalam diri manusia. Sehingga, belajar di lembaga pendidikan tidak hanya untuk kecerdasan intelektual tetapi juga cerdas secara emosi dan spiritual. Sehingga peserta didik menjadi manusia yang dengan intelektualnya dapat memberikan kemanfaatan, bijaksana dalam mengambil keputusan, sopan dalam bersikap dan yang terpenting sesuai dengan nilai-nilai agama Islam. Karena sudah jelas mana yang dibolehkan yang akan memberikan manfaat dan mana yang dilarang karena berdampak merusak atau merugikan. Hal tersebut dapat dilakukan sesuai dengan keunikan masing-masing peserta didik.

Setiap manusia memiliki keunikan, diantara keunikannya: kebutuhan, kepribadian, inteligensi, bakat, motif dan motivasi, minat, perhatian, sikap, kebiasaan. Yang kesemuanya, secara khas mempengaruhi perilakunya (Hartono, dkk, 2013: 77). Sehingga memiliki berbagai masalah, yaitu: kecewa, frustrasi, kecemasan, stres, depresi, konflik, ketergantungan (Hartono, dkk, 2013: 83). Maka dengan pendidikan, semua peserta didik dipersiapkan untuk siap menghadapi kemungkinan masalah, dan memiliki ketrampilan dalam menyelesaikan masalah sesuai dengan kemampuan berpikir. Hal tersebut dapat dicontohkan oleh guru BK maupun memberikan kesempatan pengalaman menyelesaikan masalah. Dengan kemampuan akal, peserta didik dapat berpikir positif untuk menemukan solusi yang tepat sesuai dirinya dan tidak merugikan orang lain.

Di dalam al-Khawathir, Syekh Muhammad Mutawalli alSya'rawi mengatakan: "Pikiran adalah alat ukur yang digunakan manusia untuk memilih sesuatu yang dinilai lebih baik dan lebih menjamin masa depan diri dan keluarganya". Dengan berpikir, kata 
James Allan, seseorang dapat menentukan pilihannya. Dengan begitu, manusia dapat memilih yang cocok bagi diirnya dan bertanggung jawab atas pilihannya (Elfky, 2013: 3). Karena akal anak-anak akan terus berkembang optimal ketika dilatih dan dibantu aktualisasinya oleh orang dewasa dengan kesempatan pengalaman. Maka anak-anak diharapkan memiliki semangat belajar untuk melatih akal dengan memahami pengetahuan dan terampil menyelesaikan masalah. Meskipun dalam belajar ada beberapa kendala dalam memahami pengetahuan, menguasai teknologi, dan menyelesaikan masalah.

Keberhasilan usaha belajar/pendidikan seseorang dipengaruhi oleh banyak faktor (dari dalam maupun dari luar). Semangat dan minat individu, juga dorongan dan terciptanya lingkungan yang kondusif dapat mensukseskan belajar. Meskipun kadang-kadang muncul hambatan kelelahan belajar pada peserta didik atau tidak adanya kesempatan belajar, karena ikut membantu perekonomian keluarga. Sehingga individu tidak bisa berhasil dalam belajarnya atau tidak mencapai tujuan seperti yang diharapkan, misalnya:

1. Individu tidak terampil mengerjakan sesuatu yang seharusnya bisa dilakukannya setelah mempelajarnya.

2. Individu tidak juga bisa memahami pokok bahasan (materi pelajaran) tertentu kendati telah dicoba mempelajarinya sekuat tenaga.

3. Individu segan atau malas untuk mempelajari bahan pelajaran tertentu.

4. Individu sulit menyelesaikan tuas-tugas sekolah karena di rumah terlampau banyak pekerjaan yang juga harus diselesaikan.

5. Individu berkali-kali gagal menguasai bahan pelajaran yang harus dipelajarinya sesuai dengan target yang seharusnya.

Mengingat banyak ragam problem yang dihadapi atau mungkin akan dihadapi oleh seseorang yang sedang belajar atau menempuh pendidikan, baik itu yang mungkin muncul dari keadaan diri orang yang belajar maupun dari lingkungan sekitarnya, maka individu yang belajar perlu medapatkan bantuan bimbingan dan konseling pendidikan Islami agar kegiatan belajar atau pendidikannya itu mencapai hasil sebagaimana mestinya (Faqih, 


\section{Tri Sukses Melalui Bimbingan dan Konseling Pendidikan ...}

2001: 105). Dari pengetahuan yang sederhana mencapai pengetahuan yang kompleks, dari perilaku yang tidak baik menjadi perilaku yang baik, dari interaksi yang hanya dengan keluarga menjadi interaksi yang semakin luas, dari kebiasaan keluarga menjadi kebiasaan di Madrasah dan lain-lain.

Lingkungan Madrasah adalah ucapan, perilaku dan sikap para guru dan pengelola sekolah. Karena sekolah memiliki pengaruh yang cukup besar dalam proses pembelajaran, maka akan dengan mudah meniru apa yang ada di sekolah, baik yang positif maupun negatif. Semua memperkaya proses pembentukan pola pikir yang sudah ada sehingga menjadi semakin kuat di alam bawah sadar (Elfky, 2013: 8). Iklim belajar dengan pendekatan bimbingan dan konseling akan membantu peserta didik untuk tumbuh dan kembang secara optimal, baik: kognitifnya, afektifnya, maupun psikomotoriknya. Sehingga kebutuhan psikofisik peserta didik dapat terpenuhi dan teraktual untuk meraih tri sukses: akademik, karir, sosial dengan belajar di lembaga pendidikan (Madrasah dan sekolah).

Menurut pasal 27 PP No. 29 Tahun 1990: "Bimbingan merupakan bantuan yang diberikan kepada siswa dalam rangka upaya menemukan pribadi, mengenal lingkungan, dan merencanakan masa depan". Mengingat luasnya tujuan bimbingan bagi para peserta didik, tidak dapat dibantah bahwa kepala Madrasah dan guru-guru memiliki peranan dibidang bimbingan dan konseling (Willis, 2013: 29). Yang pelaksaannya melalui aturan tata tertib Madrasah dan kebijakan kepala Madrasah untuk semua tenaga kependidikan agar menggunakan pendekatan BK yang humanistik dan memahami karakteristik manusia. Sedangkan guru dapat menerapkan prinsip dan fungsi BK dalam proses pembelajaran, menerapkan azas BK dalam menyelesaikan masalah peserta didik, dengan inovasi program BK yang seuai dengan teknik verbal dan non verbal, serta beragam teknik (Home Room, Karya Wisata, Diskusi Kelompok, Kegiatan Kelompok, Organisasi Klien, Sosiodrama, Psikodrama, dan Remedial).

Kegiatan BK merupakan aktivitas yang berkelanjutan, meski dengan kemampuan konseli membantu pengembangan diri sendiri. Kareka kesuksesan konseling ketika konseli mampu mandiri untuk 
mengenali potensi dan dikembangkan secara maksimal, mampu untuk menyelesaikan masalah sesuai kondisi diri, dan mampu mengembangkan diri dengan kelebihan yang dimiliki serta meminimalisir kelemahan diri. Dan konseling sebagai proses membantu individu agar berkembang, memiliki prinsip penting yaitu: a) Memberikan kabar gembira dan kegairahan hidup. Sesuai dengan firman Allah dalam QS. 34: 28, yang artinya: "Dan kami tidak mengutus engkau (Muhammad) kecuali kepada umat manusia seluruhnya sebagai pembawa berita gembira dan sebagai pemberi peringatan", b) Melihat klien sebagai subjek dan hamba Allah. Dengan menghargai klien sebagai pribadi yang merdeka (untuk jujur dan terbuka) sehingga memberi nasehat agama agar klien introspeksi diri, c) Menghargai klien tanpa syarat. Dengan memberikan ucapan-ucapan, serta bahasa badan yang menghargai, d) Dialog Islami yang menyentuh. Agar klien memunculkan rasa syukur, rasa cinta, bahkan perasaan berdosa, karena keakraban dan keterlibatan klien adalah kata kunci dalam hubungan konseling untuk menyentuh klien pada perasaan keagamaan dan kemanusiaan, e) Keteladanan pribadi konselor. Yang dapat menyentuh perasaan klien untuk mengidentifikasi diri konselor, merupakan sugesti untuk berubah kearah positif. Motivasi untuk berubah disebabkan kepribadian, wawasan, dan ketrampilan serta amal kebajikan konselor terhadap klien (Willis, 2013: 25).

Dan proses bantun dalam kegiatan konseling diawali dengan empati, terus terjadinya kesepatakan antara konselor dengan konseli, adanya rasa nyaman dan konseli terbantukan dari kegiatan konseling untuk menemukan solusi yang efektif dan semangat untuk melaksanakan keputusan dengan mandiri dan penuh tanggung jawab. Hal tersebut dapat dipraktekkan oleh konselor sesuai kebutuhan peserta didik di lembaga pendidikan: Madrasah dan sekolah.

Sekolah sebagai institusi pendidikan mempunyai peranan yang sangat penting dalam menciptakan iklim sekolah yang kondusif. Iklim sekolah yang sehat, di samping dibutuhkan untuk membangkitkan motivasi belajar peserta didik, juga diperlukan untuk mengantisipasi timbulnya perasaan tidak nyaman yang akan mempengaruhi prestasi belajar (Desmita, 2014: 302). Oleh 


\section{Tri Sukses Melalui Bimbingan dan Konseling Pendidikan ...}

karenanya, persiapan-pelaksanaan-evaluasi belajar dapat dibantu semua tenaga kependidikan yang menggunakan pendekatan bimbingan dan konseling. Baik tujuan, fungsi, program, teknik, azas serta dampak dari kegiatan bimbingan dan konseling di Madrasah. Meskipun tetap mengikuti kebutuhan terkini peserta didik serta penggunaan media teknologi untuk memudahkan data-data klien serta pertukaran informasi lintas budaya yang memudahkan penerapan bimbingan dan konseling yang sesuai dengan landasan orientasi baru di lembaga pendidikan.

Orientasi baru BK yang bersifat pengembangan dengan landasan filosofis dari orientasi baru yaitu: (1) Pedagogis artinya menciptakan kondisi sekolah yang kondusif bagi perkembangan peserta didik dengan memperhatikan perbedaan individual, (2) Potensial artinya setiap peserta didik adalah manusia yang memiliki potensi untuk dikembangkan, sedangkan kelemahannya secara berangsur akan diatasinya sendiri, (3) Humanistik religius artinya pendekatan terhadap peserta didik haruslah manusiawi dengan landasan Ketuhanan, manusia dianggap sanggup mengembangkan diri dan potensinya, (4) Profesional yaitu proses bimbingan dan konseling harus dilakukan secara profesioal atas dasar filosofis, teoritis yang berwawasan, dan ketrampilan teknik konseling yang bervariasi dari konselor (Willis, 2013: 28). Sehingga dengan peran bimbingan dan konseling pendidikan akan membantu peserta didik meraih tri sukses, karena dukungan dari semua tenaga kependidikan yang telah memahami keilmuan dan ragam pelayanan yang sesuai dengan kebutuhan peserta didik. Dan untuk layanan bimbingan dan konseling yang profesional dibutuhkan pemahaman ilmu BK, pelatihan BK, waktu, kesungguhan konselor, penanganan problemproblem (akademik, karir, sosial), diskusi dengan teman sejawat konselor, evaluasi program BK serta pemanfaatan media teknologi.

Diakui bahwa bimbingan dan konseling di Madrasah merupakan salah satu disiplin ilmu yang secara profesional memberikan pelayanan bimbingan kepada peserta didik. Dengan pelayanan yang baik akan tercipta suatu iklim yang kondusif serta menciptakan masyarakat yang berakhlak dan bermoral (Hasyim, dkk, 2010: 5). Maka kepala Madrasah, wali kelas, guru mata pelajaran dapat memberikan berbagai pengalaman, yaitu: akademik dengan 
berbagai informasi ilmu pengetahuan, motivasi untuk meraih masa depan, serta perilaku sosial yang sesuai dengan norma (sosial dan agama). Oleh karenanya, keberadaan BK di lembaga pendidikan sangat dibutuhkan untuk mencetak peserta didik yang sempurna. Meskipun penerapan BK, selalu membutuhkan upaya-upaya yang tepat sesuai karakteristik peserta didik.

Upaya tenaga kependidikan dengan pendekatan bimbingan dan konseling, diantaranya: (1) Menciptakan suasana pembelajaran yang menyenangkan, apabila bertolak dari potensi-minat-kebutuhan peserta didik. Oleh karena itu, strategi pembelajaran berpusat pada peserta didik agar dapat mengekspresikan diri dan berperan aktif, (2) Guru mengembangkan sense of humor sesuai etika dan tidak memojokkan peserta didik, (3) Kegiatan selingan "game atau ice break saat kelas tidak kondusif, (4) Sewaktu-waktu mengajak kegiatan pembelajaran di luar kelas, (5) Memberikan materi dan tugas akademik dengan tingkat kesulitan yang moderat, (6) Pendekatan humanistik dengan pola akrab, ramah, toleran, penuh kecintaan dan penghargaan, (7) Mengembangkan sistem penilaian yang menyenangkan "umpan balik positif" dan objektivitas (Hasyim, dkk, 2010: 225), sehingga terjalin hubungan yang harmonis dalam suasana pembelajaran. Peserta didik dapat menikmati proses belajar dengan menyenangkan, menumbuhkan minat dan bakat, serta semangat untuk mendapatkan berbagai pengalaman (baik pengalaman sukses ataupun gagal).

Latar belakang perkembangan profesi konseling tidak dapat dipisahkan dari dua jalur penanganan terhadap masalah-masalah yang dihadapi masyarakat Barat, yaitu tradisi penyembuhan gangguan mental dan penanganan masalah-masalah pendidikan dan pekerjaan di sekolah. Sedangkan cikal bakal profesi konseling dari segi penanganan terhadap masalah-masalah pendidikan dan vokasional diungkap dalam berbagai literature (Latipun, 2001: 21). Sehingga peserta didik menjadi semangat belajar, mengikuti kegiatan ekstra kurikuler yang melatih berorganisasi, mencari informasi tentang program studi yang sesuai, melanjutkan jenjang pendidikan, serta peluang kerja setelah selesai wajib belajar. Maka penerapan BK di Indonesia dan di Barat disesuaikan karakteristik dan kebutuhan konseli, tuntutan budaya, serta capaian dari tujuan pendidikan. 


\section{Tri Sukses Melalui Bimbingan dan Konseling Pendidikan ...}

Menurut buku Dasar Standarisasi Profesi Konseling, Depdiknas (2004), yaitu:

1. Konseling adalah pelayanan bantuan psiko pendidikan dalan bingkai budaya. Pelayanan konseling dikemas dengan acuan dasar ilmu pendidikan dan psikologi yang diwarnai budaya pihak-pihak yang terkait, khususnya budaya konseli yaitu individu yang mendapatkan pelayanan konseling.

2. Konseling adalah profesi bantuan yang diabdikan untuk meningkatkan harkat dan martabat kemanusiaan dengan cara memfasilitasi perkembangan individu atau kelompok sesuai kemampuan potensialnya dan kemampuan aktualnya serta peluang-peluang yang dimilikinya, dan membantu mengatasi kelemahan dan hambatan serta kendala yang dihadapi dalam perkembangan dirinya.

3. Konseling adalah pelayanan bantuan dengan menggunakan kerangka berpikir dan bertindak yang bernuansa kemanusiaan dan keindividuan, sehingga tidak lagi hanya dipelajari sebagai seperangkat teknik, melainkan pengembangan konseling diorientasikan pada kondisi masyarakat yang berbasis pengetahuan yang menempatkan kemanusiaan dan belajar sepanjang hayat.

4. Konseling adalah pelayanan bantuan yang berorientasi dari kondisi supply side ke demand side yang menuntut upaya proaktif konselor dalam melayani konseli dengan menggunakan berbagai sumber dan teknologi informasi untuk memperkaya peran profesional, mengembangkan manajemen informasi dan jaringan kerja, serta memanfaatkan berbagai jalur dan setting layanan baik formal maupun non formal.

5. Konseling adalah suatu profesi yang terbuka dan berkembang selaras dengan perkembangan ilmu pengetahuan, teknologi dan seni serta tuntutan lingkungan akademis dan profesional, sehingga mampu memberikan kontribusi yang signifikan bagi dunia pendidikan nasional dan kehidupan masyarakat (Hartono, dkk, 2013: 30).

Pemahaman standarisasi profesi konselor menjadi pijakan bagi guru BK untuk membuat, melaksanakan dan mengevaluasi program BK yang tepat untuk peserta didik. Profesi BK yang 
profesional tergantung pada pribadi masing-masing guru untuk melaksanakan tugas mengajar (sukses akademik), memberikan keteladanan perilaku baik (sukses karir), dan membantu menyelesaikan masalah peserta didik (sukses sosial). Di mana tri sukses tersebut disesuaikan dengan nilai-nilai Islam, yaitu: saling menasehati dan berkasih sayang dalam kebaikan, menjadi guru bagi orang-orang yang kurang pintar, saling membantu dalam interaksi dengan lingkungan, semua kegiatan pendidikan tergantung "niat hanya kepada Allah". Sehingga tri sukses selaras dengan bimbingan pendidikan Islam.

Bimbingan pendidikan Islami adalah proses pemberian bantuan terhadap individu agar kegiatan belajar atau pendidikannya senantiasa selaras dengan tujuan pendidikan Islami, yaitu menjadi insan kamil sebagai sarana mencapai kebahagiaan hidup di dunia dan akhirat. Konseling pendidikan Islami adalah proses pemberian bantuan terhadap individu agar mampu mengatasi segala hambatan dalam kegiatan belajar atau pendidikannya, dengan menyadari eksistensinya sebagai makhluk Allah yang harus senantiasa mengikuti ketentuan dan petunjuk Allah agar menjadi insan kamil, sebagai sarana mencapai kebahagiaan di dunia dan akhirat (Faqih, 2001: 106). Karena dengan belajar di lembaga pendidikan, semua potensi peserta didik dapat teraktual, serta kemampuan akal dapat digunakan berpikir dalam mendapatkan berbagai informasi dan menyelesaikan beragam permasalahan atau berpikir menemukan inovasi-inovasi yang bermanfaat. Hal tersebut, sesuai dengan tujuan bimbingan dan konseling yang dilakukan oleh guru BK dalam kegiatan pembelajaran.

Kegiatan bimbingan dan konseling untuk membantu peserta didik untuk mandiri dan tanggung jawab, sesuai dengan tujuan konseling yaitu: (1) Konseli menjadi lebih menyadari diri, bergerak ke arah kesadaran yang lebih penuh atas kehidupan batinnya dan menjadi kurang melakukan penyangkalan dan pendistorsian, (2) Konseli menerima tanggung jawab yang lebih besar atas siapa dirinya, menerima perasaan-perasaannya sendiri, menghindari tindakan menyalahkan lingkungan dan orang lain atas keadaan dirinya, dan menyadari bahwa sekarang bertanggung jawab untuk apa yang dilakukannya, (3) Konseli menjadi lebih berpegang pada 


\section{Tri Sukses Melalui Bimbingan dan Konseling Pendidikan ...}

ketentuan-ketentuan batin dan pribadinya sendiri, menghindari tindakan-tindakan memainkan peran orang yang tak berdaya, dan menerima kekuatan yang dimilikinya untuk mengubah kehidupannya sendiri, (4) Konseli memperjelas nilai-nilainya sendiri, mengambil perspektif yang lebih jelas atas masalah-masalah yang dihadapinya, dan menemukan dalam dirinya penyelesaianpenyelesaian bagi konflik-konflik yang dialaminya, (5) Konseli menjadi lebih terintegrasi serta menghadapi, mengakui, menerima, dan menangani aspek-aspek dirinya yang terpecah dan diingkari, dan mengintegrasikan semua perasaan dan pengalaman ke dalam seluruh hidupnya, (6) Konseli belajar mengambil risiko yang akan membuka pintu-pintu ke arah cara-cara hidup yang baru serta menghargai kehidupan dengan ketidakpastiannya, yang diperlukan bagi pembangunan landasan untuk pertumbuhan, (7) Konseli menjadi lebih memercayai dirinya sendiri untuk melakukan apa yang dipilih untuk dilakukannya, dan (8) konseli menjadi lebih sadar atas alaternatif-alternatif yang mungkin serta bersedia memilih bagi dirinya sendiri dan menerima konsekuensi-konsekuensi dari pilihannya (Hartono, dkk, 2013: 32). Tujuan BK tersebut yang menjadi acuan guru BK dalam melaksanakan pendampingan kepada peserta didik dalam meraih tri sukses. Selain tujuan BK, yang perlu dipahami oleh guru BK adalah pemahaman tentang obyek garapan BK pendidikan Islami.

Obyek garapan bimbingan dan konseling pendidikan Islami berkaitan dengan problem-problem, yaitu: (1) Efisiensi dan efektivitas kegiatan belajar, yakni bagaimana bisa berhasil menguasai apa yang dipelajari/diajarkan dengan efisien. Bagaimana cara belajar yang efektif, bagaimana cara mencegah terkena sanksi dikeluarkan (drop out) karena tidak memenuhi syarat penguasaan bahan pelajaran, bagaimana menghadapi kebosanan dan keengganan dan sebagainya, (2) Ketetapan pemilihan bidang/jenis studi. Jelasnya bagaimana memilih bidang studi (jurusan) yang sesuai dengan bakat, kemampuan, (3) Kelanjutan studi, berkaitan dengan pemilihan melanjutkan studi ataukah tidak dan dalam bidang apa, khususnya melanjutkan studi ke perguruan tinggi (Faqih, 2001: 113). Yang sesuai dengan tri sukses di lembaga pendidikan. Maka apapun yang dilakukan oleh guru BK pada hakekatnya adalah membantu peserta 
didik untuk mengenali diri agar meraih tri sukses. Maka bimbingan dan konseling pada prinsipnya hanya merupakan bantuan kepada individu, artinya pelaksanaan kegiatan mencegah dan memecahkan masalah-masalah pendidikan yang mungkin dihadapi, merupakan kegiatan individu yang dibantu diri sendiri. Oleh karena itu, bimbingan dan konseling pendidikan Islami pada dasarnya sekedar membantu individu mengetahui masalah yang dihadapinya, mengetahui kondisi atau kekuatan-kelemahan diri, dan membantu mencari alternatif yang sesuai dengan dirinya sendiri.

Peserta didik yang beragama Islam dapat dibantu dengan BK pendidikan Islami, karena permasalahan akademik, karir dan sosial dapat diatasi dengan cara yang tepat sesuai dengan nilai Islam agar terhindar dari gangguan mental "putus asa". Karena pserta didik selalu memiliki keyakinan dalam setiap usaha disertai dengan do'a: memohon kepada Allah untuk solusi yang efektif dan efisien. Bahkan dengan beragam masalah yang dihadapi peserta didik menumbuhkan: kesadaran tentang kebutuhan sosial untuk tolong menolong sesama manusia, berserah diri hanya kepada Allah (iman kepada Allah), berdoa dengan tulus penuh kesabaran dan lain-lain yang akan mejadikan peserta didik bersikap tenang dan percaya diri. Secara rinci tujuan bimbingan dan konseling pendidikan Islami, yaitu:

1. Membantu individu mencegah timbulnya problem-problem yang berkaitan dengan kegiatan belajar/pendidikannya: membantu individu memahami hakikat belajar/pendidikan menurut Islam, membantu individu memahami tujuan dan kedudukan belajar/pendidikan menurut Islam, membantu individu memahami faktor-faktor yang mempengaruhi keberhasilan belajar/pendidikan, membantu individu menyiasati kegiatan belajar/pendidikan agar berhasil, membantu individu melakukan kegiatan belajar/pendidikan sesuai ketentuan (syariat) Islam.

2. Membantu individu memecahkan masalah yang berkaitan dengan belajar/pendidikan: membantu individu agar mampu memahami (menganalisis dan mendiagnosis) problem yang dihadapinya, membantu individu memahami kondisi dirinya dan lingkungannya, membantu individu memahami dan menghayati 


\section{Tri Sukses Melalui Bimbingan dan Konseling Pendidikan ...}

cara-cara mengatasi masalah belajar/pendidikan menurut ajaran Islam, membantu individu menetapkan pilihan upaya pemecahan masalah yang dihadapinya sesuai ajaran Islam.

3. Membantu individu memelihara situasi dan kondisi kegiatan belajar/pendidikannya agar tetap baik dan mengembangkannya agar jauh lebih baik: memelihara individu memelihara situasi dan kondisi belajar/pendidikannya yang semula pernah terkena problem dan telah teratasi agar tidak menjadi permasalahan kembali, mengembangkan situasi dan kondisi belajar/pendidikan menjadi lebih baik (Faqih, 2001: 107).

Semua pendidik, termasuk di dalamnya konselor melakukan kegiatan pembelajaran, penilaian, pembimbingan dan pelatihan dengan berbagai muatan dalam ranah belajar kognitif, afektif, psikomotor, serta keimanan dan ketakwaan kepada Tuhan Yang Maha Esa (Hasyim, dkk, 2010: 8). Karena tri sukses yang diraih peserta didik pada hakekatnya adalah untuk memahami tentang amanah sebagai mahkluk Allah dengan tugas khalifah dan abdillah. Belajar yang diniati ibadah akan mendapatkan ilmu yang barokah (memberikan kemanfaatan), melanjutkan pendidikan (kewajiban mencari ilmu dari turun ayunan sampai ke liang lahat) dan bekerja sebagai sarana untuk mendapatkan rezeki yang halal, serta sesama manusia adalah saudara sehingga saling berkasih sayang bahkan menjaga kelestarian lingkungan menjadi salah satu tugas khalifatullah. Maka tri sukses yang sesuai dengan azas BK Pendidikan Islami yang akan memberikan kemanfaatan dunia akhirat, sesuai keyakinan pemeluk agama Islam yang beriman pada hari akhir. Karena bimbingan dan konseling Pendidikan Islam dilakukan oleh guru berdasar pada asas-asas yang mengarahkan pada kebenaran ajaran Islam.

Asas-asas bimbingan dan konseling pendidikan Islami sebagai berikut: kebahagiaan dunia akhirat, kewajiban menuntut ilmu, pendidikan seumur hidup, manfaat pendidikan, multipengaruh terhadap pendidikan, kesesuaian dengan keadaan diri, dan produktivitas. Sehingga seorang guru bimbingan dan konseling pendidikan Islam seyogyanya memiliki kompetensi, diantaranya: menguasai ilmu bimbingan dan konseling, memahami (memiliki) wawasan pendidikan, khususnya yang berkaitan dengan kegiatan 
belajar-mengajar (termasuk psikologi pendidikan, psikologi perkembangan dan lain-lain), memahami syariah Islamiyah yang memadai. Selain persyaratan tersebut, masih ada lagi persyaratan personal atau kepribadian (akhlak mulia) dan kemampuan berkomunikasi dengan baik (Faqih, 2001: 94). Sehingga seorang guru BK pendidikan Islam memiliki "nilai lebih" dalam melaksanakan bimbingan dan konseling, karena tri sukses yang dilakukan untuk peserta didik sesuai dengan landasan religius, yaitu: nilai keberkahan ilmu, nilai ibadah dan pahala, serta keridhaan Allah untuk keselamatan dunia-akhirat yang memenuhi kesempurnaan kebutuhan peserta didik (baik fisik, psikis, sosial, spiritual).

Landasan religius dalam layanan bimbingan dan konseling ditekankan pada tiga hal, yaitu: (1) manusia sebagai makhluk Tuhan, (2) sikap yang mendorong perkembangan dari perikehidupan manusia berjalan ke arah dan sesuai dengan kaidah-kaidah agama, dan (3) upaya yang memungkinkan berkembang dan dimanfaatkannya secara optimal suasana dan perangkat budaya (termasuk ilmu pengetahuan dan teknologi) serta kemasyarakatan yang sesuai dengan dan meneguhkan kehidupan beragama untuk membantu perkembangan dan pemecahan masalah (Hasyim, dkk, 2010: 12). Karena permasalahan yang dihadapi peserta didik sejatinya dikembalikan kepada Allah yang akan memberikan petunjuk jalan keluar dengan arahan dan bimbingan guru BK yang religius, dengan memahami manusia adalah makhluk yang unik dengan kelebihan (akal dan komunikasi) dan memiliki kebebasan (meskipun ada batasnya) berkehendak.

Kebebasan merupakan prinsip dasar, dengan karakteristik kebebasan ini membedakan manusia dengan binatang. Manusia memiliki kebebasan, memiliki kemampuan untuk memutuskan rantai stimulus respon yang kaku yang memperbudak binatang. Pikiran yang sehat mampu menahan berbagai dorongan yang berbeda dalam keadaan keseimbangan yang tidak pasti, dan akhirnya memutuskan dorongan mana yang menang. Yang dari sudut pandang psikologis, penting untuk meyakini pemilikan kebebasan manusia dalam rangka mendapatkan gambaran yang tepat tentang kepribadian sebagai dasar konseling yang efektif (May, 2003: 11). Dengan kelebihan akal dan komunikasi, peserta didik dapat memilih 


\section{Tri Sukses Melalui Bimbingan dan Konseling Pendidikan ...}

yang terbaik untuk diri sendiri dan tidak merugikan orang lain. Oleh karenanya, melibatkan penalaran-persepsi ketika proses konseling agar muncul kesadaran dan pemahaman yang tepat tentang permasalahan tri sukses dan dapat menemukan solusi yang tepat dalam meraih tri sukses: akademik, karir dan sosial. Dengan aktualisasi dan optimalisasi kemampuan kognitif peserta didik maka pendekatan bimbingan dan konseling pendidikan Islam dapat berdampak positif dalam membentuk kepribadian Islam peserta didik.

Pendekatan kognitif-perilaku dikembangkan atas prinsip dasar bahwa pola pemikiran manusia terbentuk melalui proses rangkaian stimulus-kognisi-respon (SKR), yang saling berkait dan membentuk semacam jaringan SKR dalam otak manusia. Dalam rangkaian SKR ini, proses kognitif memainkan peranan penting dan menjadi faktor penentu dalam memengaruhi perilaku manusia, bagaimana manusia berpikir, merasa dan bertindak sikap-sikap, harapan, atribusi, dan berbagai kegiatan kognitif lainnya merupakan kekuatan utama dalam menghasilkan, memprediksi dan memahami perilaku. Menurut ahli teori kognitif-perilaku, memahami cara-cara individu menginterpretasikan peristiwa-peristiwa lingkungan sama pentingnya dengan peristiwa itu sendiri, dan interpretasi individu terhadap peristiwa lingkungan tersebut memngaruhi cara-cara individu dalam bertindak (Desmita, 2014: 302), yaitu: memaknai masalah, menyelesaikan dengan cara-cara yang tepat, mengembangkan diri dengan harapan-harapan yang lebih baik. Hal tersebut dapat dilakukan peserta didik dengan kemampuan berpikir, yang akan menuntun kebijaksanaan perasaan dan ketepatan sikap beradaptasi dengan lingkungan.

Prinsip dasar yang memandang proses kognitif sebagai rangkaian terpadu dengan perilaku manusia, diimplementasikan dalam program terapi dan konseling, sehingga melahirkan terapi kognitif-perilaku, diarahkan kepada modifikasi fungsi berpikir, merasa dan bertindak dengan menekankan peran otak dalam menganalisis, memutuskan, bertanya, berbuat dan memutuskan kembali. Dengan mengubah status pikiran dan perasaannya, peserta didik dapat merubah tingkah lakunya, dari negatif ke positif. Menurut Deffenbacker bahwa suatu paradigma konseling yang sangat 
menjanjikan bagi psikoedukasional dan program prevensi. Maka sangat cocok untuk digunakan sebagai bagian dari upaya-upaya psikologi pendidikan yang terencana (Desmita, 2014: 303). Maka dengan mengaktifkan otak yang mengontrol seluruh aktivitas tubuh manusia, dapat terpenuhi semua kebutuhan peserta didik dalam meraih tri sukses. Karena pendekatan bimbingan dan konseling pendidikan Islami akan mengarahkan berpikir manusia untuk menerima-menyimpan-memunculkan kembali beragam informasi ilmu pengetahuan, mengarahkan berpikir manusia untuk memiliki kepekaan-kepeduliaan-kebijaksanaan untuk berkarir meraih cita-cita masa depan, mengarahkan berpikir manusia untuk berkasih sayangmenghargai-bermanfaat untuk diri sendiri dan lingkungan. Dengan berpikir positif berdasar kepada keyakinan kepada Allah, maka peserta didik akan dapat mencegah munculnya masalah, dapat mengatasi masalah, dan mengenali potensi-potensi diri untuk menjadi makhluk Allah yang sempurna dalam menjalankan amanah khalifatullah dan abdillah.

\section{Simpulan}

Lembaga pendidikan (Madrasah dan sekolah) menjadi tempat kedua bagi anak-anak untuk belajar dan mendapatkan beragam pengalaman. Menjadi peserta didik adalah kesempatan untuk menyempurnakan tugas-tugas perkembangan, mengoptimalkan semua potensi yang dimiliki sehingga meraih tri sukses: akademik, karir, dan sosial. Dalam mewujudkan tri sukses sangat mungkin ditemui kendala, sehingga tenaga kependidikan dengan pendekatan bimbingan dan konseling pendidikan Islam dapat memberikan bantuan kepada peserta didik dengan iklim belajar yang kondusif. Peserta didik memiliki keunikan, kelebihan "akal pikiran dan komunikasi", kebebasan berkehendak yang dapat dibantu dengan arahan dari guru BK agar mampu mengenali kelebihan dan kelemahan diri, potensi-potensi, serta keyakinan "iman kepada Allah". Hal tersebut, menjadikan peserta didik dapat memenuhi kebutuhan fisiknya untuk bebas beraktivitas, kebutuhan psikisnya untuk nyaman dan senang menjadi manusia pembelajar, kebutuhan sosialnya untuk menjadi bagian dari lingkungan sosial, kebutuhan religius untuk menjalankan amanah Allah dengan 
Tri Sukses Melalui Bimbingan dan Konseling Pendidikan ...

keyakinan pertolonganNya. Iklim belajar yang menggunakan pendekatan bimbingan dan konseling pendidikan Islami dapat membantu peserta didik menjadi manusia sempurna dan bermanfaat. 


\section{Farida}

\section{Daftar Pustaka}

Desmita, 2014, Psikologi Perkembangan Peserta Didik, Bandung: Remaja Rosdakarya

Elfky, Ibrahim, 2013, Terapi Berpikir Positif: Biarkan Mukjizat dalam

Diri Anda Melesat Agar Hidup Lebih Sukses dan Lebih Bahagia. Terj: Khalifurrahman Fath dan M. Taufik Damas, Bandung: Zaman

Faqih, Aunur Rahim, 2001, Bimbingan dan Konseling Dalam Islam, Jogjakarta: UII Press

Hartono dan Soemardji, Boy, 2013, Psikologi Konseling, Jakarta: Kencana, Prenada Media Group

Hasyim, Farid dan Mulyono, 2010, Bimbingan dan Konseling Religius, Jogjakarta: Ar-Ruzz Media

Latipun, 2001, Psikologi Konseling, Malang: UMM Press

May, Rollo, 2003, Seni Konseling (Judul Asli: The Art of Counseling), Yogyakarta: Pustaka Pelajar

Willis, Sofyan S, 2013, Konseling Individual, Teori dan Praktek, Bandung: Alfabeta 